\title{
Impact of river discharge, upwelling and vertical mixing on the nutrient loading and productivity of the Canadian Beaufort Shelf
}

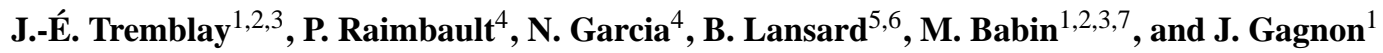 \\ ${ }^{1}$ Québec-Océan \& Départment de biologie, Université Laval, Québec, QC, Canada \\ ${ }^{2}$ Takuvik Joint International Laboratory, Département de Biologie, Université Laval, Québec, Qc, Canada \\ ${ }^{3}$ Takuvik Joint International Laboratory, CNRS, Québec, Qc, Canada \\ ${ }^{4}$ Aix-Marseille University, Mediterranean Institute of Oceanography (MIO), UMR7294, CNRS/INSU, UMR235, IRD, \\ 13288, Marseille, Cedex 09; Université du Sud Toulon-Var (MIO), 83957, La Garde CEDEX, France \\ ${ }^{5}$ Department of Earth and Planetary Sciences-GEOTOP, McGill University, Montréal, Canada \\ ${ }^{6}$ LSCE, IPSL-CEA-CNRS-UVSQ, Gif-sur-Yvette, France \\ ${ }^{7}$ Laboratoire d'Océanographie de Villefranche, Université Pierre et Marie Curie, BP8, 06238 Villefranche-sur-Mer CEDEX, \\ France
}

Correspondence to: J.-É. Tremblay (jean-eric.tremblay@bio.ulaval.ca)

Received: 22 August 2013 - Published in Biogeosciences Discuss.: 29 October 2013

Revised: 27 June 2014 - Accepted: 16 July 2014 - Published: 11 September 2014

\begin{abstract}
The concentrations and elemental stoichiometry of particulate and dissolved pools of carbon $(\mathrm{C})$, nitrogen $(\mathrm{N})$, phosphorus $(\mathrm{P})$ and silicon ( $\mathrm{Si}$ ) on the Canadian Beaufort Shelf during summer 2009 (MALINA program) were assessed and compared with those of surface waters provided by the Mackenzie river as well as by winter mixing and upwelling of upper halocline waters at the shelf break. Neritic surface waters showed a clear enrichment in dissolved and particulate organic carbon (DOC and POC, respectively), nitrate, total particulate nitrogen (TPN) and dissolved organic nitrogen (DON) originating from the river. Silicate as well as bulk DON and DOC declined in a near-conservative manner away from the delta's outlet, whereas nitrate dropped nonconservatively to very low background concentrations inside the brackish zone. By contrast, the excess of soluble reactive $\mathrm{P}$ (SRP) present in oceanic waters declined in a nonconservative manner toward the river outlet, where concentrations were very low and consistent with $\mathrm{P}$ shortage in the Mackenzie River. These opposite gradients imply that the admixture of Pacific-derived, SRP-rich water is necessary to allow phytoplankton to use river-derived nitrate and to a lesser extent DON. A coarse budget based on concurrent estimates of primary production shows that river $\mathrm{N}$ deliveries support a modest fraction of primary production when considering the entire shelf, due to the ability of phytoplankton
\end{abstract}

to thrive in the subsurface chlorophyll maximum beneath the thin, nitrate-depleted river plume. Away from shallow coastal bays, local elevations in the concentration of primary production and dissolved organic constituents were consistent with upwelling at the shelf break. By contrast with shallow winter mixing, nutrient deliveries by North American rivers and upwelling relax surface communities from $\mathrm{N}$ limitation and permit a more extant utilization of the excess SRP entering through the Bering Strait. In this context, increased nitrogen supply by rivers and upwelling potentially alters the vertical distribution of the excess $\mathrm{P}$ exported into the North Atlantic.

\section{Introduction}

The Arctic Ocean is currently experiencing severe and rapid physical changes that are expected to alter primary productivity as well as the structure and function of marine food webs. In the Arctic, the ability of photosynthetic algae to profit from the greater irradiance resulting from the demise of sea ice is ultimately constrained by the availability of nitrogen $(\mathrm{N})$, which was shown to explain large regional differences in annual productivity at the pan-arctic scale (Tremblay and Gagnon, 2009). This condition partly results from the physical setting, whereby strong, persistent and increasing 
vertical stratification in the interior impedes the vertical renewal of nutrients across the halocline (Tremblay et al., 2008; Li et al., 2009; Codispoti et al., 2013).

While any process conducive to the erosion of the halocline or upwelling will inject more nutrients into the upper euphotic zone, the unusual stoichiometry (or mixture) of nutrients imposes an additional constraint on productivity in the Pacific sector of the Arctic Ocean. In these waters, a chronic deficiency of $\mathrm{N}$ relative to phosphorus $(\mathrm{P})$ is maintained by a host of local and remote biogeochemical processes. In the eastern Pacific, the remineralization of Prich organic matter exported from the surface in upwelling areas combines with denitrification and anaerobic ammonium oxidation in oxygen minimum zones to lower the $\mathrm{N}: \mathrm{P}$ ratio of waters that eventually ascend in the subarctic $\mathrm{Pa}$ cific (e.g. Mills and Arrigo, 2010; Kalvelage et al., 2011). As these waters move northward, their $\mathrm{N}: \mathrm{P}$ ratio is further reduced by coupled nitrification-denitrification on shallow Arctic shelves (Granger et al., 2011). The ensuing N deficiency in the high Arctic limits the ability of phytoplankton to fully use $\mathrm{P}$ and silicon $(\mathrm{Si})$, which remain in excess at the surface and are ultimately exported into the North Atlantic Ocean (Torres-Valdés et al., 2013; Yamamoto-Kawai et al., 2006). Conversely, North American rivers tend to deliver Pdeficient waters (Le Fouest et al., 2013), but their impact on primary production and on the nutrient composition of waters exiting the high Arctic is not well understood.

The Canadian Beaufort Shelf is a narrow interior shelf exposed to discharge from the Mackenzie River and shelfbreak upwelling (Tremblay et al., 2011; Carmack and MacDonald, 2002) (Fig. 1). Its location along the eastward path of Alaskan coastal water and at the southern margin of the Beaufort Gyre makes it sensitive to upstream water mass history, but also implies that it can modify the biogeochemical properties of waters exiting the Arctic through the Canadian Archipelago. The Mackenzie is the fourth largest river draining the Arctic Ocean and the largest single source of sediments to the coastal zone (Holmes et al., 2002). The region harbors vital feeding and staging areas for marine mammals and marine birds that depend on primary production at the base of the food web (Carmack and MacDonald, 2002). While significant knowledge of nutrient transport by Arctic rivers has been gained and synthesized recently (Holmes et al., 2012), the biogeochemistry of estuaries and contiguous shelves is understudied by comparison with other estuarine systems at lower latitudes (Moritz et al., 2002; McClelland et al., 2012). Recent modeling studies suggest a minor influence of rivers on inorganic nutrient loading at the pan-Arctic scale (Tank et al., 2012; Le Fouest et al., 2013), but field investigations considering both inorganic and organic constituents as well as their local and far-field biogeochemical impacts remain scarce and fragmentary.

Previous investigations of the Canadian Beaufort shelf focussed on brackish waters in Kugmallit Bay (Emmerton et al., 2008a, b; Retamal et al., 2008) and occurred during a year

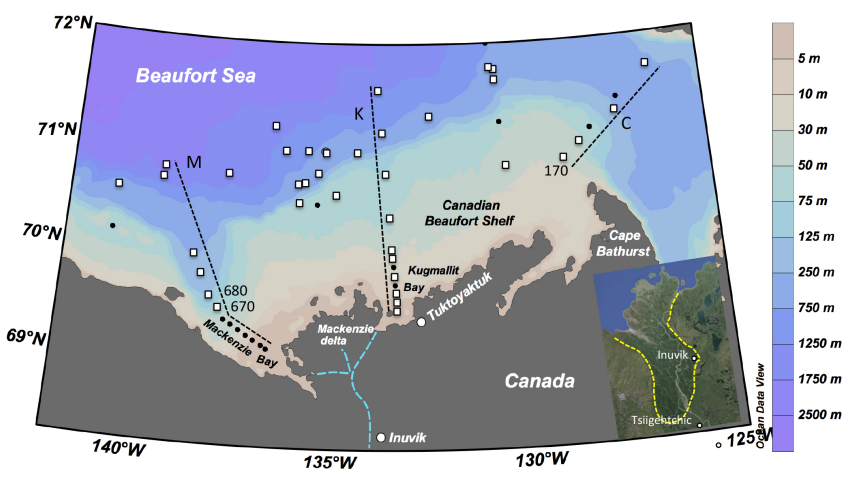

Figure 1. Map of sampling stations in the Mackenzie River (inset) and the southeast Beaufort Sea, with locations where inorganic nutrient concentrations were determined (all symbols) and where primary production and the particulate and dissolved organic pools of carbon, nitrogen and phosphorus were also quantified (squares). Samples were taken at the surface only for stations located inside the 30 and $50 \mathrm{~m}$ isobaths in Kugmallit Bay and Mackenzie Bay, respectively. Black dashes and capital letters mark the vertical sections presented in the subsequent figures. Yellow dashes coarsely define the contours of the delta region (inset). To avoid visual clutter, only the few stations discussed specifically in the text are identified.

of relatively low discharge. Characteristics of the western arm in Mackenzie Bay were not established and the marine "end-member" sites considered by these studies were relatively neritic. A comparison between riverine and oceanic nutrient sources (e.g. upwelling, vertical mixing and advection) considering quantity, stoichiometry and their importance for primary production relative to local recycling processes remains to be achieved at different spatial scales, which is the main objective of the present study. Our working hypotheses were that nutrient supply by the Mackenzie River makes a highly localized and small overall contribution to new primary production on the Canadian Beaufort Shelf and that this production is contingent on the mixing of $\mathrm{P}$-deficient freshwater with $\mathrm{N}$-deficient seawater. Measurements of inorganic and organic constituents were performed in the Mackenzie River, in the estuarine transition zones of Mackenzie and Kugmallit bays, as well as in the marine domains of the inner and outer Mackenzie Shelf and the southeast Canada Basin during spring and summer 2009. These results are compared with late-winter, pre-bloom data from the adjacent Amundsen Gulf to provide seasonal and regional perspectives on nutrient availability and ratios. Finally, estimates of river nutrient deliveries to the inner shelf were compared with in vitro measurements of nitrogen uptake and primary production to elucidate nutrient recycling processes in the estuarine transition zone. 


\section{Materials and methods}

\subsection{General}

Oceanographic sampling took place from 2 July to $25 \mathrm{Au}-$ gust 2009 during the Mackenzie Light and Carbon (MALINA) expedition of the CCGS Amundsen to the southeast Beaufort Sea (Fig. 1). High vertical resolution environmental data were collected between 0 and up to $500 \mathrm{~m}$ depth using a conductivity-temperature-depth-oxygen profiler (CTDO, Seabird 911 plus) with a rosette supporting 24 $12 \mathrm{~L}$ Niskin bottles equipped with silicon rubber closures. Salinity values are reported in the practical salinity scale, without units. Surface samples from the Mackenzie River plume in the shallow portions of Mackenzie Bay and Kugmallit Bay were collected with a bucket from a barge. A water mass analysis assessing the contribution of meteoric water (Mackenzie River runoff + precipitation) and sea-ice melt water to the different sampling stations was performed using alkalinity and $\delta^{18} \mathrm{O}$ data according to procedures previously described for our sampling area (Lansard et al., 2012). This data will be presented elsewhere and here is used only to discuss the validity of salinity as a tracer of river water.

\subsection{Inorganic nutrients}

Ammonium concentrations were measured using the sensitive method of Holmes et al. (1999) with a detection limit of $5 \mathrm{nM}$. Samples for nitrate, nitrite, soluble reactive phosphorus (SRP) and silicate determination, were collected into $20 \mathrm{~mL}$ polyethylene flasks and immediately poisoned with mercuric chloride $\left(10 \mu \mathrm{g} \mathrm{mL}^{-1}\right)$, according to Kirkwood (1992), and stored for subsequent laboratory analysis. Nitrate and nitrite concentrations in the nanomolar range (lower detection limit $=3 \mathrm{nM}$ ) were obtained using the sensitive method of Raimbault et al. (1990). Nitrate in deep waters (detection limit $=0.05 \mu \mathrm{M}$ ) and phosphate (detection limit $=0.02 \mu \mathrm{M}$ ) were measured according to the method of Aminot and Kerouel (2007). To ensure the reproducibility of nutrient measurements between analyses, in-house standards were used, which were regularly compared to the commercially available products (OSIL). Winter nutrient samples collected in the adjacent Amundsen Gulf during the IPYInternational Circumpolar Flaw Lead Study in 2008 were determined using similar procedures as outlined in Tremblay et al. (2008). Deviations of nitrate and SRP concentrations from the $\mathrm{N}$ : $\mathrm{P}$ ratio $(r)$ of biological drawdown and remineralization, which are assumed equivalent, were assessed with the parameters $\mathrm{N}^{*}$ and $\mathrm{P}^{*}$ (Gruber and Sarmiento, 1997):

$$
\begin{aligned}
\mathrm{N}^{*} & =\text { nitrate }-(r \cdot \mathrm{SRP}) \\
\mathrm{P}^{*} & =\mathrm{SRP}-(\text { nitrate } / r)
\end{aligned}
$$

Since the $\mathrm{N}$ : $\mathrm{P}$ ratio of drawdown during blooms in the Beaufort Sea (12.6-13.7; Tremblay et al., 2008; Bergeron and
Tremblay, 2014) is lower than the globally averaged Redfield value of 16 (Gruber and Sarmiento, 1997), we prescribed a mean $r$ value of 13.1 to better compare nutrient availability and demand in our survey region. For instance, a $\mathrm{N}^{*}$ value of $-5 \mu \mathrm{M}$ indicates that complete utilization of the available SRP by phytoplankton would require the addition of $5 \mu \mathrm{M}$ DIN to the system.

\subsection{Organic constituents}

Samples for particulate organic carbon (POC) and total particulate nitrogen (TPN) and phosphorus (TPP) were filtered onto glass fiber filters (Whatman GF/F, $25 \mathrm{~mm}$ in diameter, $0.7 \mu \mathrm{m}$ pore size) pre-combusted at $500^{\circ} \mathrm{C}$ for $4 \mathrm{~h}$. Between 250 to $1200 \mathrm{~mL}$ of sample was filtered depending on the quantity of particulate matter in the sample. Following filtration, filters were washed with $100 \mu \mathrm{L}$ of $\mathrm{H}_{2} \mathrm{SO}_{4}(0.5 \mathrm{~N})$ to remove inorganic carbon. The filters were then stored in $25 \mathrm{~mL}$ Schott glass bottles for subsequent laboratory analysis. Blank filters were prepared for each set of samples by washing the filter with $200 \mathrm{~mL}$ of $0.2 \mu \mathrm{m}$-filtered seawater. Determination of POC, TPN and TPP was carried out simultaneously on the same sample using the wet-oxidation procedure described in Raimbault et al. (1999b).

Samples for total organic matter determination were collected directly from the Niskin bottles into $50 \mathrm{~mL}$ Glass Schott bottles. Samples were immediately acidified with $100 \mu \mathrm{L}$ of $0.5 \mathrm{~N} \mathrm{H}_{2} \mathrm{SO}_{4}$ and stored in the dark at $5^{\circ} \mathrm{C}$ until analytical determination at the home laboratory. Prior to oxidation, samples were bubbled with a high purity oxygen/nitrogen gas stream for $15 \mathrm{~min}$. Persulfate wet-oxidation was used to digest the organic matter in these unfiltered samples and the inorganic end-products were determined according to Raimbault et al. (1999a). The calibration was made according to the range of the marine content observed. Total organic nitrogen and total organic phosphorus were calculated as total nitrogen and phosphorus minus dissolved inorganic nitrogen (nitrate + nitrite + ammonium) or phosphate measured in the same samples. Dissolved organic carbon (DOC), dissolved organic nitrogen (DON) and dissolved organic phosphorus (DOP) were calculated by subtracting values of POC, TPN and TPP in the $>$ GF/F fractions (see above) from the unfiltered totals. The analytical accuracy was ca. 5.0, 0.5 and $0.05 \mu \mathrm{M}$ for DOC, DON and DOP, respectively. Deep Sargasso Sea reference water was used to verify the analytical calibration for carbon content $(45 \pm 0.5 \mu \mathrm{M}$, Hansell Laboratory, Bermuda Biological Station for Research). All reagents and sample blanks were prepared using fresh Millipore Milli-Q plus ${ }^{\circledR}$ water.

\subsection{River discharge and nutrient transport by the Mackenzie River}

Two river sites were used during our study. Given the complex branching of the river in the delta region, discharge 
data were taken only from the Environment Canada station at Tsiigehtchic (http://www.wsc.ec.gc.ca/applications/ $\mathrm{H} 2 \mathrm{O} /$ ), which is located $200 \mathrm{~km}$ inland in the main body of the river (Supplement). Water samples were obtained during the period of peak discharge at Tsiigehtchic (25 May, 3 June and 11 June 2009) and at Inuvik (daily from 23 May to 11 June 2009). The latter is located at the head of the delta, $100 \mathrm{~km}$ downstream of Tsiigehtchic. Surface water was taken with a clean plastic bucket, filtered through pre-combusted Whatman GF/F filters and frozen. Dissolved inorganic and organic constituents were subsequently analyzed as above. The concentrations of these constituents as well as concomitant discharge data are given in Supplement (Table S1). To facilitate comparison with shelf data, we calculated median and discharge-weighted mean concentrations at Inuvik for the period between 25 May and 11 June (Supplement Table S1). Discharge-weighted means were obtained by multiplying daily discharge (Tsiigehtchic) by concentration (Inuvik), summing all time points and dividing by cumulative discharge. Estimates of nutrient transport for the main MALINA sampling period (July-August) and the whole year were calculated by assuming a steady decrease in concentrations from those measured at peak discharge and those measured during the MALINA sampling on the shelf. Since the main emphasis of this paper is on the estuarine transition zone and the shelf, the data pertaining to discharge and nutrient concentrations in the Mackenzie River are confined to the Supplement.

\subsection{Primary production and nitrogen uptake}

Rates of carbon fixation (primary production) and of nitrate and ammonium uptake were measured at a subset of stations using a dual ${ }^{13} \mathrm{C}-{ }^{15} \mathrm{~N}$ isotopic technique (Raimbault et al., $1999 \mathrm{c})$. For this purpose, $580 \mathrm{~mL}$ samples were collected at 6-7 depths between the surface and the depth where irradiance is $0.3 \%$ of its surface value, and poured into acidcleaned polycarbonate flasks. Bottles were rinsed before use with $10 \% \mathrm{HCl}$, then with ultra-pure Milli-Q water. Radiolabeled sodium bicarbonate $\left(\mathrm{NaH}^{13} \mathrm{CO}_{3}-6 \mathrm{~g}, 250 \mathrm{~mL}^{-1}\right.$ deionized water -99 at $\%{ }^{13} \mathrm{C}$, EURISOTOP) was added to each bottle in order to obtain $\approx 10 \%$ final enrichment $\left(0.5 \mathrm{~mL}\right.$ per $580 \mathrm{~mL}$ sea water). Nitrogen ${ }^{15} \mathrm{~N}$-tracer additions, $\mathrm{K}^{15} \mathrm{NO}_{3}$ or ${ }^{15} \mathrm{NH}_{4} \mathrm{Cl}\left(99 \%\right.$ at $\left.{ }^{15} \mathrm{~N}\right)$, were 10 or $20 \%$ of the ambient concentration based on measurements made on previous casts. In nutrient impoverished waters, when concentrations were lower than the detection limit, additions of ${ }^{15} \mathrm{~N}$ were fixed at $\sim 17 \pm 3 \mathrm{nM}$ for ${ }^{15} \mathrm{~N}-\mathrm{NO}_{3}$ and $43 \pm 3 \mathrm{nM}$ for ${ }^{15} \mathrm{~N}-\mathrm{NH}_{4}$.

Incubations were started immediately following tracer addition, just before dawn in an on-deck incubator. The latter consisted of 6-7 compartments, each covered with a bluelight screen allowing the samples of a given location collected at different depths to be exposed to the light 50,25, $15,8,4,1$ and $0.3 \%$ of incident sunlight. The incubator was maintained at sea-surface temperature using pumped seawa- ter. After $24 \mathrm{~h}$ samples were filtered through precombusted $\left(450^{\circ} \mathrm{C}\right)$ Whatman $\mathrm{GF} / \mathrm{F}$ filters using a low vacuum pressure $(<100 \mathrm{~mm} \mathrm{Hg})$. Following filtration, filters were placed into $2 \mathrm{ml}$ glass tubes, dried for $24 \mathrm{~h}$ in a $60^{\circ} \mathrm{C}$ oven and stored dry until laboratory analysis. These filters were used to determine the final ${ }^{15} \mathrm{~N} /{ }^{13} \mathrm{C}$ enrichment ratio in the particulate organic matter and the concentrations of particulate carbon and particulate nitrogen. The dual isotopic enrichment analysis was performed on an Integra-CN mass spectrometer calibrated using international reference material (glycine) every $10-15$ samples.

\section{Results}

\subsection{River discharge and nutrient transport}

Historical data indicate that annual discharge during 2009 was greater than the long term mean, ranking 8th for the period 1972-2009 (Supplement Fig. S1). For 2009, daily discharge reached a peak of $30000 \mathrm{~m}^{3} \mathrm{~s}^{-1}$ on 27 May, remained very high until the end of June, and decreased to ca. $50 \%$ of the peak value during July, August and September. A comparison with a year of low discharge (2004) shows that high discharge in 2009 did not result from a particularly strong freshet but from persistently elevated transport from June to September (Supplement Fig. S1).

Concentrations of DON and DOC measured at river sites during May and June and on the shelf at stations with negligible salinity $(<0.23)$ during August were related exponentially to daily river discharge (Supplement Table S1 and Fig. S2). By contrast, high and low concentrations of DOP alternated throughout the sampling period with no apparent relationship to discharge (Supplement Table S1). This relationship was also absent for nitrate and phosphate although maximum concentrations occurred during the freshet. Phosphate concentrations fluctuated widely relative to other constituents $(\mathrm{CV}>100 \%)$, which drove high variability in nitrate: SRP and $\mathrm{N}^{*}$. Roughly $25 \%$ of the annual seaward transport occurred during July and August for all constituents (Table 1). The ratio of organic to inorganic forms in the overall transport was much larger for nitrogen (5.6) than for phosphorous (2.3).

\subsection{Distribution of inorganic and organic constituents on the shelf}

Surface distributions of salinity and dissolved constituents on the shelf are shown in Fig. 2. The river signal was strongest in Mackenzie Bay, where salinity ranged from $0.15-0.23$, at the two southernmost stations (collectively referred to as "river outlet" hereafter), to 15 in the outer bay at $69.3^{\circ} \mathrm{N}$. By contrast, the minimum inshore salinity observed in Kugmallit Bay was 16.4. Nutrients showed strong inshore-offshore gradients. Surface concentrations of nitrate and silicate were highest (3.62 and $64.5 \mu \mathrm{M}$, respectively) at the river outlet 

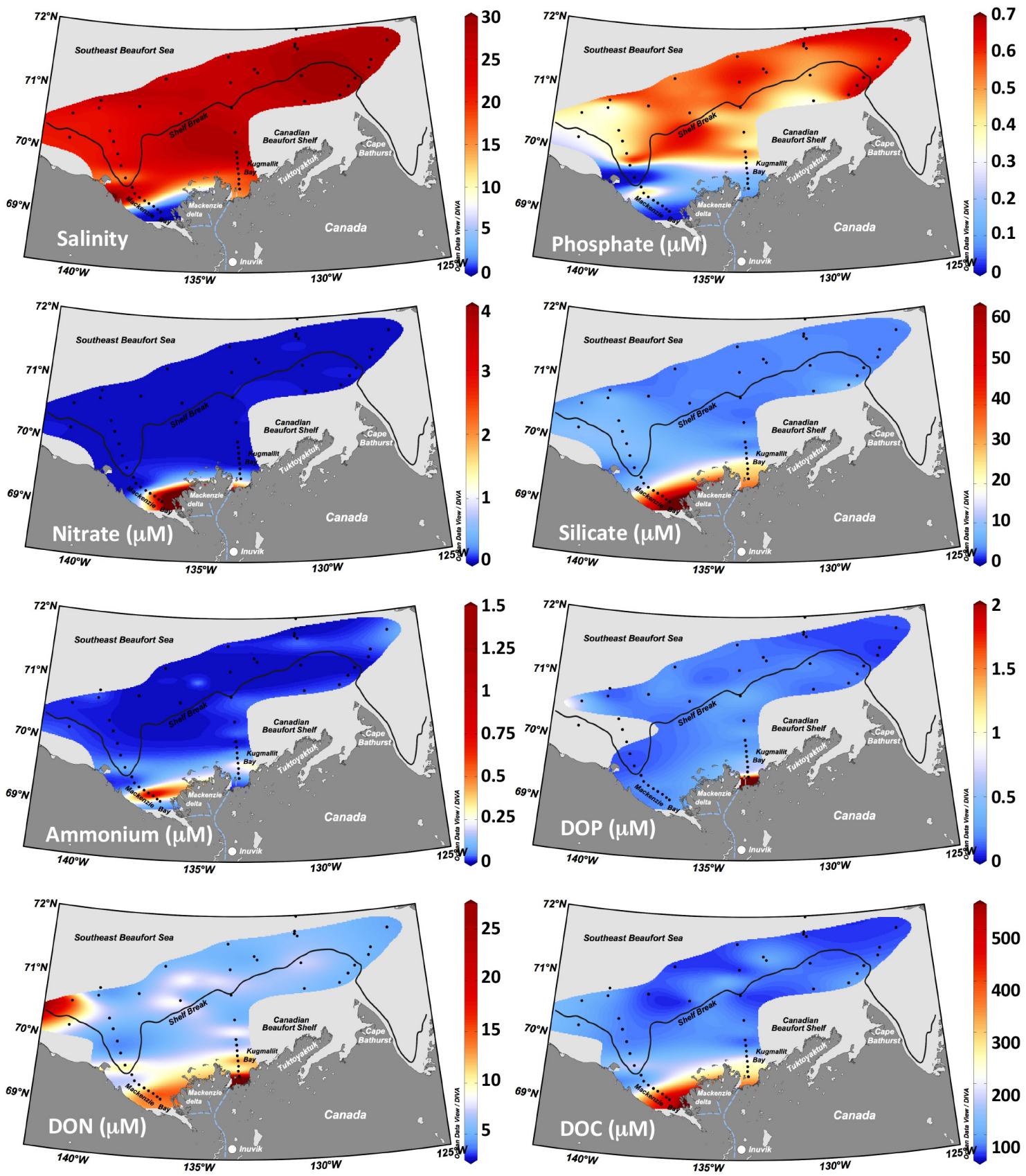

Figure 2. Surface distributions of salinity, nitrate, ammonium, DON, phosphate, silicate, DOP and DOC in the coastal Beaufort Sea during July and August 2009. The mean position of the shelf break is indicated by the black line (75 $\mathrm{m}$ isobath).

and declined seaward to low values for silicate $(>3 \mu \mathrm{M})$ and measurable trace levels for nitrate $(0.005$ to $0.02 \mu \mathrm{M})$.

Spatial gradients in dissolved organic $\mathrm{N}$ and $\mathrm{P}$ were similar to those of nitrate, but this time the highest concentrations were observed in Kugmallit Bay, with maxima of 26.7 and $1.33 \mu \mathrm{M}$ for DON and DOP, respectively. Corresponding concentrations in inner Mackenzie Bay were only 15.2 and $0.22 \mu \mathrm{M}$. Offshore concentrations were generally much lower, ranging from 4.43 to $8.0 \mu \mathrm{M}$ for DON and from 0.09 to $0.33 \mu \mathrm{M}$ for DOP. Phosphate showed opposite spatial gradients, with a minimum concentration of $0.02 \mu \mathrm{M}$ observed at the river outlet and a seaward increase to concentrations ranging from 0.40 to $0.67 \mu \mathrm{M}$ offshore. Ammonium concentrations in Mackenzie Bay were low at the river outlet $(0.20 \mu \mathrm{M})$, increased to a maximum of $1.48 \mu \mathrm{M}$ in the central part and declined to very low but always detectable levels offshore $(0.01-0.05 \mu \mathrm{M})$. A qualitatively similar pattern was 
observed in Kugmallit Bay, but the highest observed concentration was only $0.34 \mu \mathrm{M}$ in the center of the bay.

Figure 3 shows the vertical distribution of a subset of dissolved properties along the three sections identified in Fig. 1. Seaward intrusions of freshwater from both arms of the Mackenzie River were confined to the upper $10 \mathrm{~m}$ on sections $\mathrm{C}$ and $\mathrm{K}$. Sections $\mathrm{C}$ and $\mathrm{M}$ and to a lesser extent section $\mathrm{K}$ showed a shoreward uplifting of intermediate offshore waters, which resulted in elevated nitrate concentrations and nitrate:SRP ratios over the bottom on the outer and middle shelf. The shallow end of section $\mathrm{C}$ was characterized by nitrate concentrations ranging from 2 to $4 \mu \mathrm{M}$ between 15 and $20 \mathrm{~m}$ as well as elevated ammonium levels over the bottom (station 170, $30 \mathrm{~m}$ deep). Concentrations of ammonium and DON qualitatively followed a similar pattern, with maximum surface concentrations in central Kugmallit and Mackenzie bays and bottom accumulations over the shelf and slope. Maximum nitrate : SRP ratios at the surface were observed nearshore and rapidly declined seaward, where a strong vertical gradient was present on all sections.

Since the influence of the Mackenzie river plume was confined to the upper $10 \mathrm{~m}$ (mixed layer depths ranged 5-10 $\mathrm{m}$ on the inner shelf), we investigated how the concentrations of different constituents changed as a function of salinity in this layer. Properties at the river outlet in inner Mackenzie Bay were considered as undiluted (surface salinities $<0.23$ ) and representative of "pristine" river waters on the shelf. Inorganic nutrient concentrations in this area were highly similar to the median and discharge-weighted concentrations observed at Inuvik during May and June (Fig. 4). The agreement was better with the median, which is less affected by extreme values during the freshet. On the shelf, each constituent should theoretically vary with salinity along a conservative mixing line in the absence of net gains or losses resulting from chemical or biological processes. Such conservative behavior roughly applied to silicate, $\mathrm{N}^{*}$ (hence $\mathrm{P}^{*}$ ) but not to DIN, DIP nor SRP. Nitrate and SRP showed opposite, non-conservative gradients, while ammonium showed a clear accumulation at intermediate salinities. The nitrate : SRP ratio increased markedly between the river and inner Mackenzie Bay and then decreased abruptly with rising salinity. Nitrate, SRP and silicate all showed conspicuously low concentrations at the head of Mackenzie Canyon (stas. 670 and 680 ) with a surface salinity of ca. 15. This station was located in the outskirts of Mackenzie Bay in the west. By contrast, the concentrations of silicate and $\mathrm{N}^{*}$ at similar salinities in Kugmallit Bay loosely followed the general conservative dilution line. In Kugmallit Bay, daily nitrate uptake declined seaward with increasing salinity and decreasing nitrate availability (Fig. 4). No spatial gradient was discernible in ammonium uptake, which remained relatively high across the bay and accounted for 50 to $86 \%$ of total inorganic $\mathrm{N}$ uptake (i.e. sum of ammonium + nitrate uptake).

Concentrations of DON and DOC in the river were higher than on the shelf and, by contrast with DOP, showed a clear conservative decrease with salinity (Fig. 5). All ratios decreased between the river outlet and marine waters with salinities $>25$, but the relative decrease was most pronounced for DOC : DOP $(4 \times)$, followed by DOC: DON $(2.6 \times)$ and DON : DOP $(1.5 \times)$, suggesting a differential lowering of $\mathrm{C}$ (carbon) relative to $\mathrm{N}$ and $\mathrm{P}$. Only the DOC:DON ratio showed a linear decrease with salinity. The overall $\mathrm{C}: \mathrm{N}: \mathrm{P}$ stoichiometry of DOM in the river $(2419: 48: 1$, based on discharge-weighted means) and at the river outlet in Mackenzie Bay $(2085: 63: 1)$ was similar but very different from the area of maximum DOM in Kugmallit Bay (149:13:1) and the average for marine stations with salinities above 25 $(451: 35: 1)$.

Primary production and particulate organic constituents also showed clear inshore-offshore gradients (Fig. 6). Daily rates of primary production at the surface where generally very low across the survey area, ranging from $0.1 \mu \mathrm{g} \mathrm{C} \mathrm{L}-1 \mathrm{~d}^{-1}$ offshore to a maximum $545 \mu \mathrm{g} \mathrm{C} \mathrm{L}-1 \mathrm{~d}^{-1}$ in Kugmallit Bay at a salinity of 16 (Fig. 6). The estimated turnover time of the suspended POC pool (i.e. POC divided by primary production) was 2 days at this location, which also exhibited the highest concentrations of POC and TPN on the transect. An exception to this general pattern occurred in the notoriously upwelling-prone area to the northwest of Cape Bathurst, where primary production, POC and TPN were clearly elevated. In Mackenzie Bay, concentrations of POC, TPN and TPP were 52.02, 8.34 and $4.96 \mu \mathrm{M}$, respectively, at the river outlet (salinity $=0.15$ ), rose to $72.83,12.51$ and $5.47 \mu \mathrm{M}$ at the next station (salinity $=0.23$ ) and declined to minimum values of $1.68,0.33$ and $0.03 \mu \mathrm{M}$ offshore. When excluding the upwelling area, TPN and POC showed a somewhat progressive decline with rising salinity across the shelf, in stark contrast with the sharp drop of TPP at the beginning of the estuarine transition zone (Fig. 7). Despite a tendency toward higher values at the marine end of the salinity gradient, POC: TPN values clustered around the Redfield value (6.7) across the whole sampling area, which contrasted with seaward increases in TPN: TPP and to a lesser extent POC : TPP (Fig. 7). The overall stoichiometry of particulate organic matter at the river outlet $(10.5: 1.7: 1)$ differed from that of marine waters with salinities $>25(107: 7.6: 1)$. At the delta's outlet in Mackenzie Bay, nearly all $(95 \%)$ of the total phosphorus (SRP+DOP+TPP) was in the particulate pool. For nitrogen the particulate fraction represented only $31 \%$ of the total.

\section{Discussion}

The importance of inorganic and organic river nutrients for biological productivity on a given shelf depends on (1) the width and area of the shelf relative to river transport, (2) the extent to which these nutrients can be used by autotrophs, either directly or after microbial and/or photochemical transformation, and (3) the strength of oceanic nutrient deliveries 


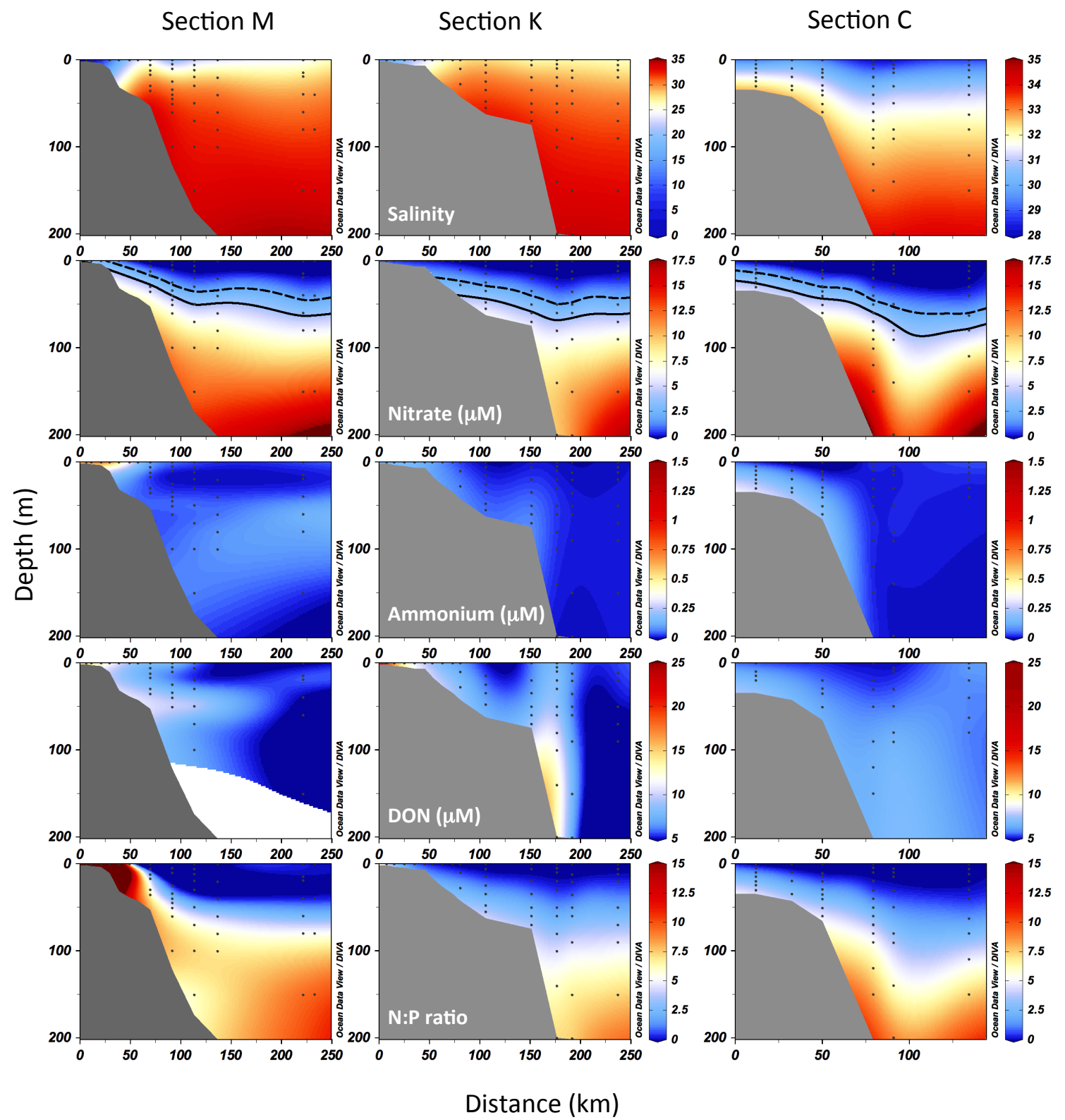

Figure 3. Vertical distributions of salinity, nitrate, ammonium, DON and the nitrate : SRP ratio along sections M, K and C. The location of each section is given in Fig. 1. The dashed and solid lines indicate the depths where nitrate concentrations equate 2 and $4 \mu \mathrm{M}$, respectively.

through horizontal advection, vertical mixing and upwelling. In addition to their direct effects on local productivity, different oceanic and riverine sources of nutrients to the euphotic zone impact the magnitude and composition of surface nutrient fluxes to downstream areas. Effects on composition (or nutrient ratios) are manifest when the nutrient mixtures provided differ from biological demand and leave surpluses of one or more nutrients, such as the excess $\mathrm{P}$ and Si that are exported from the Arctic into the North Atlantic (YamamotoKawai et al., 2006; Torres-Valdés et al., 2013). The following discussion will therefore explore the implications of nutrient deliveries at both local and large scales, after assessing the quality of our river transport estimates, and considering the fate of river nutrients on the shelf and what distinguishes these nutrients from those provided by upwelling and winter convection in the area.

\subsection{Nutrients: river transport and gradients on the shelf}

The estimates of nutrient transports provided in Table 1 are based on measurements made in Inuvik during May and June and may not fully correspond to actual nutrient deliveries to the shelf due to seasonality and processes occurring through the delta. Based on model results and limited observations, 

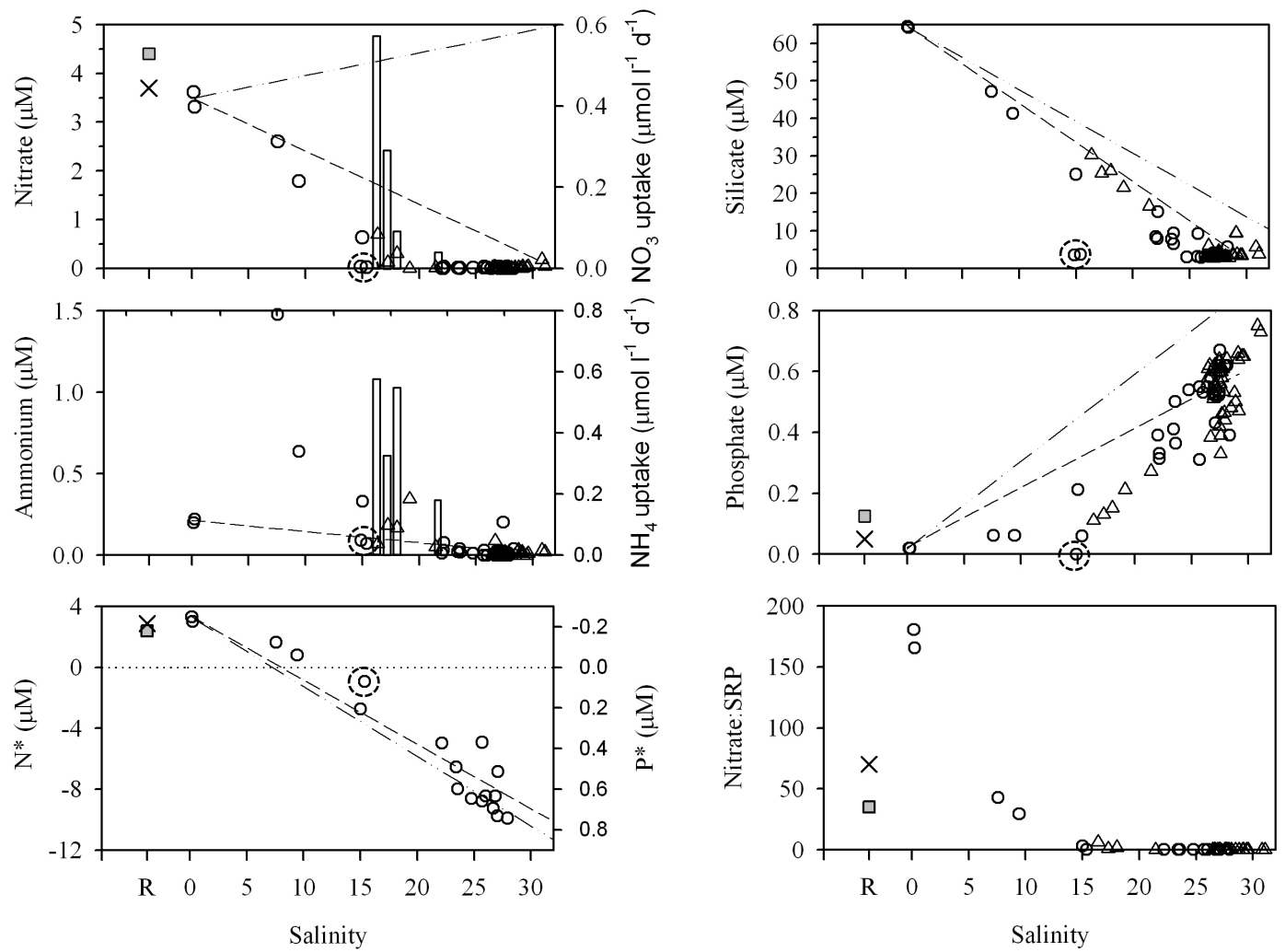

Figure 4. Concentrations of nitrate, ammonium, phosphate, silicate, $\mathrm{N}^{*}, \mathrm{P}^{*}$ and the $\mathrm{N}: \mathrm{P}$ ratio in the Mackenzie River at Inuvik (R) and on the shelf as a function of salinity during 2009 (circles $=$ marine stations west of $135^{\circ} \mathrm{W}$; triangles $=$ marine stations east of $135^{\circ} \mathrm{W}$; squares = discharge weighted mean concentration; crosses $=$ median concentration). Vertical bars indicate daily uptake rates of nitrate and ammonium estimated from ${ }^{15} \mathrm{~N}$ tracer techniques. Oblique lines provide hypothetical conservative mixing relationships between riverine and marine water-mass end-members, excluding stations that were influenced by upwelling (salinity > 30); the dashed line is the theoretical dilution line for river water mixing with summer water offshore, whereas the dash-dot-line is for river water mixing with winter offshore water (see Fig. 9b). Dashed circles indicate stations 670 and 680 (see text).

Emmerton et al. (2008b) suggested that river waters lose inorganic nutrients and gain DOM across the delta. This pattern did not seem to apply to the upper delta during our study, where limited comparisons between Tsiigehtchic and Inuvik suggest an increase in DOC, a decrease in DOP and negligible or inconsistent changes in DON, SRP and nitrate along flow (Supplement Table S1). For the lower delta, the assessment of delta effects between Inuvik and the inner shelf is complicated by the seasonal decrease in discharge. This decrease is entirely consistent with the decline in DOC and DON concentrations between Inuvik in May-June and the inner shelf in August, based on the exponential relationships linking discharge and concentration for these two constituents (established using previously published data and ours, Supplement Fig. S2; see also spring and summer data in Fig. 3 of Holmes et al., 2012). These two constituents also followed a single linear relationship (DOC $=-578+71.9$ DON; $r^{2}=0.93$; not shown) when pooling all data from Inuvik and Tsiigehtchic for May-June (Supplement Table S1) with those from the river outlet in August (Fig. 5), imply- ing consistency in their sources and biogeochemical cycling across the region. For inorganic constituents, relatively invariant concentrations across the inner shelf and the two river sites for all sampling periods suggests minor impacts by discharge and delta processes (Supplement Table S1 and Fig. 3). The lack of discharge effect was previously noted for nitrate (Holmes et al., 2012) and the concentrations of SRP and nitrate we measured here are on par with those reported for other years (Emmerton et al., 2008b; Holmes et al., 2012). This similitude and the apparent lack of change along the river's path is presumably a consequence of very low SRP levels, which presumably impeded the consumption of nitrogen through P limitation of phytoplankton and bacterial growth in the river and delta lakes (Squires and Lesack, 2003; Spears and Lesack, 2006). A corollary to this interpretation is that DOP was a minor source of labile $\mathrm{P}$ in this system.

A comparison of the overall fluxes provided in Table 1 with other published values was possible only for the annual estimates. It is noteworthy that the climatological DON and DOC fluxes estimated by Holmes et al. (2012) and Le 

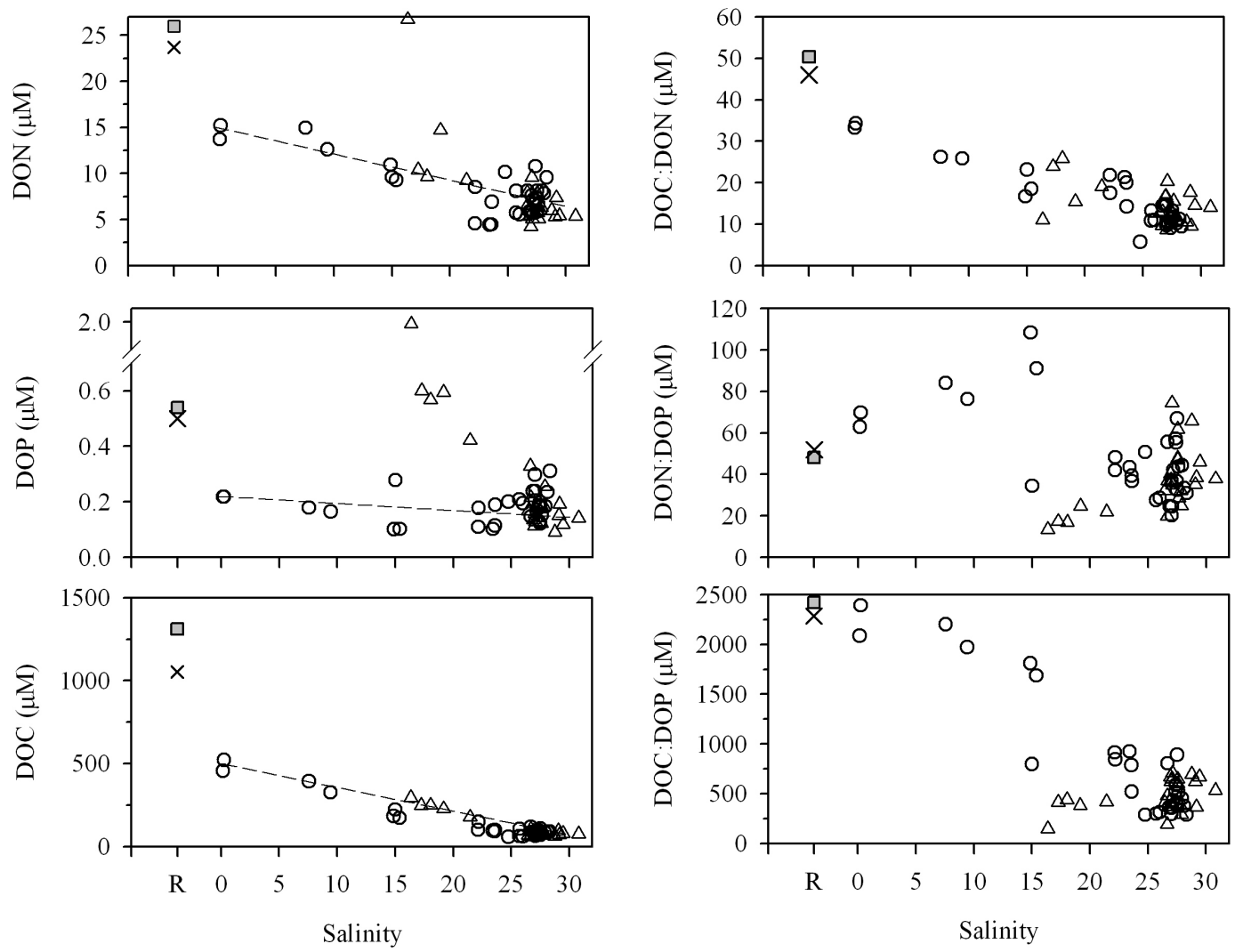

Figure 5. Concentrations of DON, DOP and DOC and elemental ratios (DOC: DON, DON : DOP and DOC: DOP) in the Mackenzie River at Inuvik (R) and over the shelf as a function of salinity during 2009 (circles $=$ stations west of $135^{\circ} \mathrm{W}$; triangles $=$ stations east of $135^{\circ} \mathrm{W}$ ). Dashed lines provide hypothetical conservative mixing relationships between riverine and marine water-mass end-members, excluding stations that were influenced by upwelling (salinity $>30$ ).

Fouest et al. (2013) were half those in Table 1, which given the above considerations can be regarded as a consequence of high discharge throughout spring and summer 2009 and, possibly, changing conditions in the watershed (e.g. thawing permafrost). By contrast, transport estimates for the dischargeindependent constituents (i.e. nitrate, TDP) were the same or within the envelope of those published by Holmes et al. (2012) and Le Fouest et al. (2013). For this reason and those discussed above we surmise that the concentrations of dissolved constituents measured in August just outside the delta were representative of river deliveries and that the nutrient transports in Table 1 provide realistic estimates of allochthonous supply to the inner shelf for 2009.

The interpretation of changes in dissolved constituents away from the southernmost stations in Mackenzie Bay and Kugmallit Bay depends on whether salinity is a valid tracer of river water in the upper $10 \mathrm{~m}$. This condition can only be met if ice melt does not introduce large amounts of freshwater at different shelf stations, which was plausible in 2009 since patchy ice floes persisted through July and early $\mathrm{Au}$ gust. A water mass analysis based on $\delta^{18} \mathrm{O}$ and total alkalinity showed robust, inverse linear relationships between
Table 1. Transports $\left(\times 10^{9} \mathrm{mmol} \mathrm{N}\right.$ or $\left.\mathrm{P}\right)$ of nitrate, SRP, total dissolved nitrogen (TDN), total dissolved phosphorus (TDP), DON and DOP by the Mackenzie River during 2009.

\begin{tabular}{lrrrrrr}
\hline & Nitrate & SRP & TDN & TDP & DON* & DOP \\
\hline July-August & 320 & 8 & 2019 & 23.9 & 1786 & 17.1 \\
Whole year & 1259 & 31 & 7922 & 100 & 6993 & 72.0 \\
\hline
\end{tabular}

* Maximum estimate calculated as $\mathrm{TDN}^{-\mathrm{NO}_{3}^{-}}$(ignores potential contribution from $\mathrm{NH}_{4}^{+}$, which is presumably small given the low concentrations observed on the inner shelf).

salinity and the fraction of meteoric water and lignin content at our sampling sites (not shown). The meteoric fraction ranged from $97 \%$ at the river outlet in Mackenzie Bay to $<5 \%$ at stations with salinities $>30$. At stations with salinities $<20$, the fraction of sea-ice melt water did not exceed $5 \%$, except at the head of Mackenzie Canyon (stations 670 and 680) where it reached $20 \%$ at salinities of ca. 15 . These stations stand out in several figures (dashed circles), most notably in Fig. 4 where silicate concentrations show a strong negative anomaly. In this case, the surface layer must have 

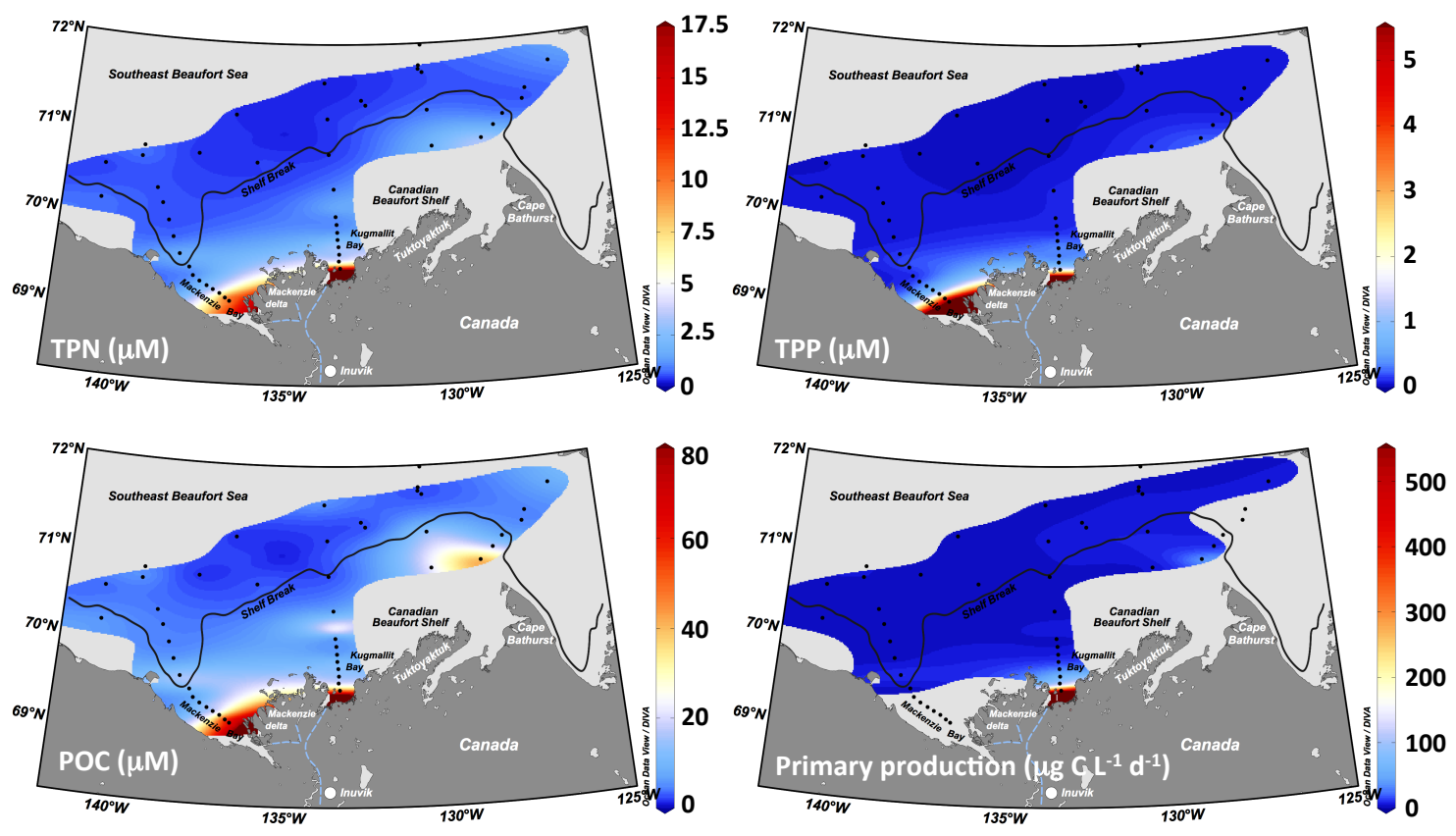

Figure 6. Distributions of (a) TPN, (b) TPP, (c) POC, and (d) primary production at the surface in the coastal Beaufort Sea during July and August 2009.

been diluted with sea-ice melt water containing little or no nutrients and subsequently affected by diatom production. Particulate stocks were not noticeably elevated at the time of sampling but TPN : TPP ratios were consistent with the $\mathrm{N}: \mathrm{P}$ drawdown ratios previously observed in diatom blooms (Tremblay et al., 2008). Apart from these two anomalous stations, all constituents would be expected to follow conservative patterns in the absence of biological processes.

\subsection{Contribution of river transport and $\mathrm{N}$ recycling to primary production}

Since there were gaps in the spatial coverage of primary production measurements, we used empirical relationships to interpolate our data vertically and across the survey area. Among static variables, the best predictor of primary production at the surface was the concentration of TPN (Supplement Fig. S3). This relationship suggests that most of the TPN was recently produced by autotrophs in the estuarine transition zone, which is consistent with the slope of the geometric mean regression of POC against TPN $\left(6.0 \pm 0.3 \mathrm{~mol} \mathrm{~mol}^{-1}\right.$, $r^{2}=0.98$; not shown) in Mackenzie and Kugmallit bays (0.15-23 salinity range) and the short turnover time of POC at the southernmost station in Kugmallit Bay. Even at the station with the highest particulate load in Mackenzie Bay (salinity of 0.15 ), the POC: TPN ratio did not exceed 5.82 (Fig. 7). This situation contrasted with the strong terrigenous matter inputs (POC : TPN ratios of up to 17) reported by Emmerton et al. (2008a).
At shallow stations $(2-20 \mathrm{~m})$ sampled from the barge, where only surface water was incubated, water-column primary production was estimated by assuming a vertical attenuation of production rates similar to observations made at station 390 on the inner shelf, noting that this may cause a slight overestimation of subsurface values at the most shallow and turbid stations $(<5 \mathrm{~m})$. To assess the importance of river nutrients for biological productivity during July and August, we compared spatially interpolated and vertically integrated primary production between the neritic sector where nitrate vanished non-conservatively at salinities $<20$, the western portion of the shelf influenced by river discharge (i.e. west of $135^{\circ} \mathrm{W}$ ) and the entire shelf (Table 2). Estimates show that the neritic sector directly influenced by river nutrients made a moderate contribution (32\%) to shelf-wide primary production although its productivity per unit area was roughly 5 times higher than the other sectors.

In order to evaluate the importance of allochthonous versus locally recycled nutrients in driving productivity $\left(112 \times 10^{9} \mathrm{~g} \mathrm{C}\right)$ in the neritic sector, the new production resulting from $\mathrm{N}_{2}$ fixation and the influx of labile river DIN and DON was assessed. Complete utilization of the nitrate supplied by the river (Table 1), which clearly occurred in the upper $10 \mathrm{~m}$ at salinities $<20$ (i.e. Fig. 4), corresponds to an equivalent new production of 23.1 and $91 \times 10^{9} \mathrm{~g} \mathrm{C}$ during July and August and the whole year, respectively, using the above $\mathrm{C}: \mathrm{N}$ ratio of $6.0 \pm 0.3$. In the absence of direct estimates, the riverine flux of ammonium during July and August can be approximated by multiplying nitrate transport (Table 1) by the ammonium : nitrate concentration ratio 

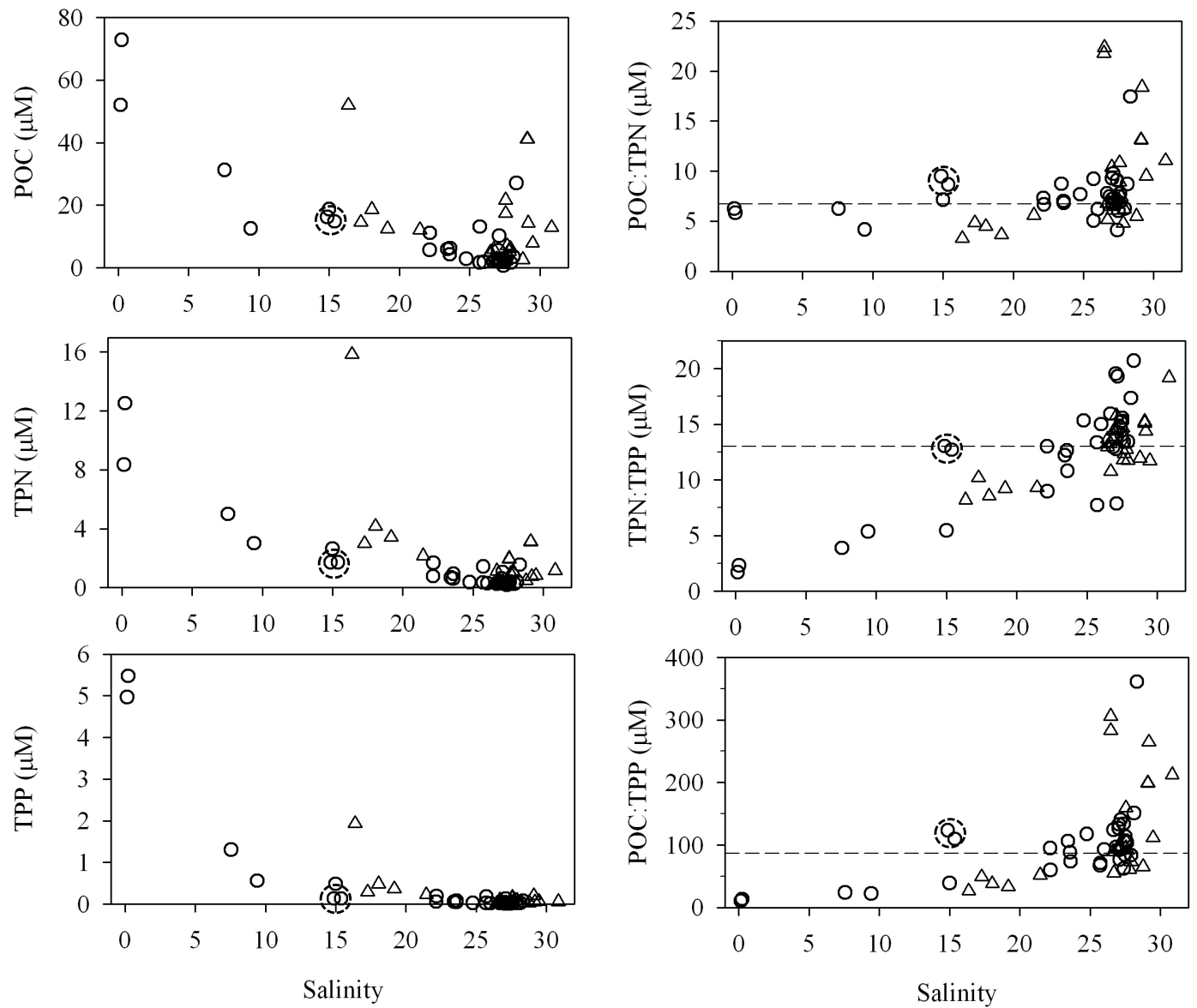

Figure 7. Concentrations of TPN, POC and TPP and elemental ratios (POC:TPN, TPN : TPP and POC:TPP) in the Mackenzie River $\left(\mathrm{T}=\mathrm{T}\right.$ siigehtchic, $\mathrm{I}=$ Inuvik) and in the upper $10 \mathrm{~m}$ over the shelf as a function of salinity during 2009 (circles $=$ stations west of $135^{\circ} \mathrm{W}$; triangles $=$ stations east of $135^{\circ} \mathrm{W}$ ). Horizontal dashed lines indicate elemental ratios of 6.7 for POC : TPN, $13.1 \mathrm{for}$ TPN : TPP and 87 for POC : TPP based on previous observations of diatom blooms in the area (see Discussion). Dashed circles indicate stations 670 and 680 (see text).

Table 2. Estimates of vertically integrated new and/or total primary production (PP) in different sectors of the Canadian Beaufort Shelf during July and August 2009 (62 days). The value in parentheses is for the upper $10 \mathrm{~m}$ only (i.e. layer directly influenced by river discharge).

\begin{tabular}{lrrr}
\hline & $\begin{array}{r}\text { Area } \\
\left(\mathrm{km}^{2}\right)\end{array}$ & $\begin{array}{r}\text { Total PP } \\
\left(\times 10^{9} \mathrm{~g} \mathrm{C}\right)\end{array}$ & $\begin{array}{r}\text { New PP } \\
\left(\times 10^{9} \mathrm{~g} \mathrm{C}\right)\end{array}$ \\
\hline Neritic sector $^{1}$ & 4132 & $121(114)$ & $30^{4}$ \\
Western portion $^{2}$ & 35069 & 215 & \\
Whole shelf $^{3}$ & 61117 & 352 & \\
\hline
\end{tabular}

${ }^{1}$ Inshore of the 20 salinity contour.

${ }^{2}$ Inshore of the $75 \mathrm{~m}$ isobath and west of $135^{\circ} \mathrm{W}$.

${ }^{3}$ Inshore of the $75 \mathrm{~m}$ isobath.

${ }^{4}$ New production driven by $\mathrm{N}_{2}$ fixation and the riverine supply of nitrate,

ammonium and total dissolved free amino acids.
$(0.2 \mu \mathrm{M} / 3.5 \mu \mathrm{M})$ at the river outlet in Mackenzie Bay. This addition rises DIN-based new production to $24.5 \times 10^{9} \mathrm{~g} \mathrm{C}$ during July and August. While the labile fraction of river DON cannot be formally assessed, the amino acid fraction (TDAA) is a viable surrogate (Benner, 2003). The mean TDAA concentration at the river outlet was $0.6 \mu \mathrm{M}$ ( $4 \%$ of total DON) during our survey (Shen et al., 2012). Adding the estimated TDAA flux (by multiplying DON transport in Table 1 by the TDAA / DON concentration ratio at the river outlet) rises new production to $29.7 \times 10^{9} \mathrm{~g}$ C during July and August. For $\mathrm{N}_{2}$ fixation, a concomitant study showed rates decreasing from 4.5 to $0.5 \mathrm{nmol} \mathrm{N} \mathrm{L}^{-1} \mathrm{~d}^{-1}$ across the estuarine transition zone (Blais et al., 2012). Prescribing a mean $\mathrm{N}_{2}$ fixation rate of $2.5 \mathrm{nmol} \mathrm{NL}^{-1} \mathrm{~d}^{-1}$ over an average depth of $5 \mathrm{~m}$ for 62 days rises total new production to $30.0 \times 10^{9} \mathrm{~g} \mathrm{C}$ during July and August (Table 2).

The above calculations yield a ratio of new $\left(30.0 \times 10^{9} \mathrm{gC}\right)$ to total $\left(114 \times 10^{9} \mathrm{~g} \mathrm{C}\right.$; based on the ${ }^{14} \mathrm{C}$ technique) production of 0.26 for the neritic sector. An 
alternate way to estimate the ratio of new to total primary production is the $f$ ratio, which is calculated by dividing nitrate uptake by the sum of nitrate and ammonium uptake (Dugdale and Goering, 1967). The average in vitro $f$ ratio calculated using the data in Fig. 4 is 0.31 , assuming that all the ammonium taken up was released by the local food web at the stations where short-term DIN uptake experiments were performed. This assumption appears reasonable given the low concentrations of ammonium at the river outlet and the maxima observed at intermediate salinities (Figs. 4 and 5). While ammonium is also provided by photochemical processes in this area, the rates estimated by Xie et al. (2012) would supply at most $1.1-3.5 \%$ of daily ammonium uptake at the surface and presumably less underneath. The two independent estimates of the ratio of new to total production ( 0.26 and 0.31 ) can be considered equivalent given our coarse approach. This match suggests that direct uptake of locally recycled DON, which reached maximum concentrations in central Kugmallit Bay (and likewise TDAA; Shen et al., 2012), contributed little to phytoplankton N demand, although it is possible for algae to use labile DON in estuaries (Tarr et al., 2001; Bushaw-Newton and Moran, 1999). The strong positive relationship between bacterial production and TDAA concentration on the shelf (OrtegaRetuerta et al., 2012) implies that bacteria were major users of fresh DON, which presumably led to the release of ammonium. Our analysis therefore suggests that nitrate was the main source of allochthonous riverine $\mathrm{N}$ supporting new production and that intense recycling supported high total primary production in the neritic sector.

The impact of the Mackenzie River on shelf productivity during summer is moderate and associated mostly with localized nutrient recycling in the nearshore estuarine transition zone. A rough annual perspective can be gained by comparing with maximum winter nutrient concentrations in nearby oceanic waters. Data from the overwintering survey of the Amundsen Gulf showed maximum nitrate concentrations of $\sim 5.0 \mu \mathrm{M}$ in mid-March 2008 (Fig. 9, see also Forest et al., 2011). Assuming a similar winter maximum across the shelf would yield a total inventory of $3.06 \times 10^{12} \mathrm{mmol}$ in the upper $10 \mathrm{~m}$ inside the $75 \mathrm{~m}$ isobath. This amount is ca. 9 times larger than the estimated annual nitrate delivery by the river (Table 1) and excludes the subsurface layer where subsurface chlorophyll maxima (SCM) thrive. The extent to which phytoplankton consume nutrients in this layer is not fully known, but given the vertical extent of seasonal depletion in Fig. 3 and previous work in adjacent Franklin Bay (Tremblay et al., 2008), it is safe to assume that the SCM consumed at least another $3 \times 10^{12} \mathrm{mmol}$ between 10 and $20 \mathrm{~m}$. In this scenario, the Mackenzie River supply would provide at most $5 \%$ of the nitrate consumed annually on the narrow Canadian Beaufort Shelf. This contribution might rise if river discharge increases, supplies more nitrogen and reinforces vertical stratification beyond the nearshore zone. Once river nutrients are consumed, freshwater remains and propagates at much larger

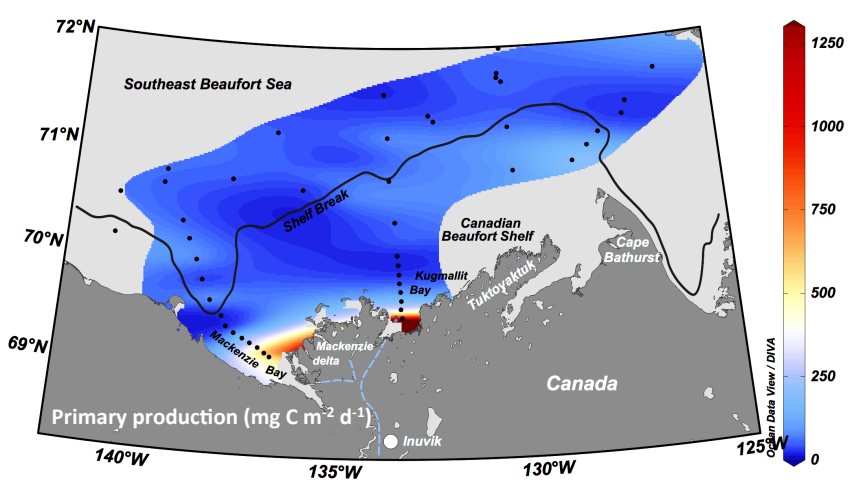

Figure 8. Spatial distribution of daily primary production during July and August on the shelf, based on a combination of direct measurements and empirical relationships (see text). The sites at which direct measurements were made are given by the white squares in Fig. 1.

scales across the Arctic. The negative impact of rivers on upward nutrient supply offshore thus reinforces their own contribution to primary production.

\subsection{Significance of river $\mathrm{N}$ supply on the Mackenzie shelf and beyond}

At present, surface marine waters of the Canada Basin and Canadian Archipelago harbor excess quantities of $\mathrm{Si}$ and SRP (= strongly positive $\mathrm{P}^{*}$, Fig. 9a) that are unused due to $\mathrm{N}$ shortage. Based on the availability of $\mathrm{P}$ alone, biological productivity in the Beaufort Sea could be 3.6 times higher than it currently is (based on winter data in Fig. 9). While the realization of this potential is susceptible to changes and variability in the nitrogen balance of source waters, it is also affected by processes occurring within the high Arctic, such as river discharge and physical oceanic processes. In this regard, phytoplankton might gain access to excess $\mathrm{P}$ in the euphotic zone through (1) a decrease in $\mathrm{N}: \mathrm{P}$ demand linked to changes in assemblage composition, (2) differential addition of labile $\mathrm{N}$ through nitrogen fixation, photochemistry or atmospheric deposition, and (3) the admixture of waters with a $\mathrm{N}: \mathrm{P}$ ratio of labile nutrients exceeding the ratio of biological demand (otherwise the nutrient input stimulates primary production, but does not lead to a reduction of the $\mathrm{P}$ surplus).

The current nitrate: SRP and $\mathrm{Si}$ : nitrate drawdown ratios of ca. 13.1 and 1.75 during blooms in the southeast Beaufort Sea are consistent with a large contribution of diatoms with an absolute requirement for Silicon and low N:P ratios (Deutsch and Weber, 2012; Geider and La Roche, 2002). The nitrate:SRP ratio is higher than the value of 9 advocated for diatom blooms in other areas (e.g. Mills and Arrigo, 2010), which could be due to a difference in diatom assemblages and the greater importance of small non-diatom taxa in the high Arctic (e.g. Micromonas, Lovejoy et al., 2007). The reported shift toward small-sized phytoplankton ( $\mathrm{Li}$ et 


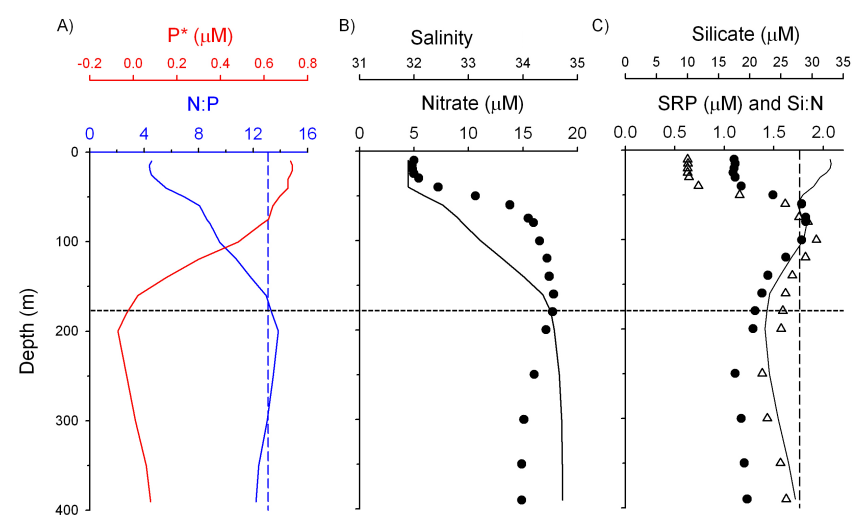

Figure 9. Vertical profiles of (a) the nitrate : SRP ratio (solid blue line; dashed blue line $=$ drawdown ratio of 13.1) and $\mathrm{P}^{*}$ (solid red line), (b) salinity (solid line) and nitrate (circles), and (c) SRP (circles), silicate (triangles) and the $\mathrm{Si}: \mathrm{N}$ ratio (solid line; dashed line $=$ drawdown ratio of 1.75) in Amundsen Gulf at the time of the winter nutrient maximum. The horizontal dashed line marks the depth of the deepest water shown to upwell at the surface on the Mackenzie shelf (from Tremblay et al., 2011).

al., 2009) in the Canada Basin potentially increases $\mathrm{N}$ : $\mathrm{P}$ demand (possibly up to 16 or even 20), further exacerbating $\mathrm{N}$ limitation, decreasing new production and rising surface $\mathrm{P}^{*}$, in agreement with the high post-bloom TPN : TPP ratios observed at the northern end of our sampling area (Fig. 7).

A comparison between pre-bloom nutrient inventories and the $\mathrm{N}$ : $\mathrm{P}$ drawdown ratio during blooms clearly reveals the large imbalance between demand and supply in the upper $140 \mathrm{~m}$ of the water column (Fig. 9a). At the height of winter, the $\mathrm{N}$ : $\mathrm{P}$ ratio of dissolved inorganic nutrients peaked at 4.5 in the upper mixed layer $(35 \mathrm{~m})$, indicating that blooms with an observed N : P demand of 13.1 can only use $34 \%$ of the available SRP before running out of nitrate. Since nutrient remineralization in the mesopelagic zone proceeds with the same stoichiometry as the organic matter exported from above (Simpson et al., 2008), the nutrients supplied to the surface during winter do not originate from the main decomposition horizon. This situation arises from the strong stratification that persists throughout winter, during which strong and coincident gradients in salinity, nitrate : SRP and $\mathrm{P}^{*}$ extend from 40 to $170 \mathrm{~m}$. The coincidence implies that nutrients are mostly trapped where they are mineralized and those reinjected to the surface during winter come from a relatively shallow N-poor horizon, dominated by advected excesses of $\mathrm{SRP}$ and $\mathrm{Si}$. This conditions allows the surface $\mathrm{P}^{*}$ anomaly to survive for several years and to propagate over large distances, providing a unique setting for nutrient deliveries by the Mackenzie River, upwelling or mixing.

A corollary to the above discussion is that nitrate : SRP ratios increase with depth in the upper $200 \mathrm{~m}$ of the Canada Basin of the Arctic Ocean, contrary to most other oceans where nitrate:SRP remains relatively stable (e.g. central north Atlantic) or decreases (e.g. eastern North Pacific) away from the surface. It follows that in the Beaufort Sea upwelling or mixing events that erode the halocline will close the gap between $\mathrm{N}$ : P supply and demand, stimulating primary production while allowing for a more complete utilization of the $\mathrm{P}$ and $\mathrm{Si}$ in the euphotic zone. Mixing is currently limited to modest winter convection in the southeast Beaufort Sea, but can be extensive in the narrow channels of the Canadian Archipelago (Michel et al., 2006; Tremblay et al., 2002) where pre-bloom $\mathrm{N}: \mathrm{P}$ ratios in the euphotic zone are twice higher than in the Beaufort Sea. Based on the profiles shown in Fig. 9, the nitrate: SRP ratio of surface waters during upwelling events should rise by 1 unit for every $17 \mathrm{~m}$ increment in entrainment depth. Indeed, surface nitrate : SRP ratios exceeding 10 and approaching the $\mathrm{N}: \mathrm{P}$ demand of blooms have been observed during strong upwelling events (Tremblay et al., 2011). Upwelling during MALINA was relatively modest, but nevertheless increased nitrate and $\mathrm{N}: \mathrm{P}$ ratios in the lower euphotic zone. Corresponding impacts on the $\mathrm{Si}: \mathrm{N}$ ratio are relatively weak since the latter deviates from the demand ratio by only $17 \%$ across the water column (Fig. 9).

Assuming a negligible sequestration of nutrients in the sediment (see Link et al., 2013) and matching stoichiometry of drawdown and remineralization in the water column, changes in the extent of $\mathrm{P}$ and Si utilization resulting from mixing or upwelling would not affect the overall export of these nutrients into the North Atlantic. Given the above considerations however, it would alter the vertical distribution of $\mathrm{P}^{*}$ in the salt-stratified outflow. By relieving $\mathrm{N}$ limitation in surface waters, greater vertical mixing, upwelling or river transport within the high Arctic would work to transfer excess $\mathrm{P}$ to depth when sinking particles are remineralized in the mesopelagic zone. A weakening of these processes would act to elevate $\mathrm{P}^{*}$ and $\mathrm{Si}^{*}$ in the upper mixed layer.

In the absence of intense mixing or upwelling at the shelf break, runoff provides the only source of relatively high nitrate: SRP water to the coastal Beaufort Sea. Riverine nitrate: SRP ratios are very high, starting at ca. 50 at Inuvik and exceeding 150 at the river outlet when nearly all of the small riverine pool of SRP has vanished. Conditions are similar in the Yukon River (Le Fouest et al., 2013). At the opposite end of the nutrient spectrum, surface marine waters of the Canada basin are nitrate-depleted and show a large excess of SRP. The mixture of both water types in the coastal zone is thus necessary to support efficient consumption of river nitrogen and explains why the parameters $\mathrm{N}^{*}$ and $\mathrm{P}^{*}$ are linearly related to salinity (Fig. 4). In this context, the net loss of nitrate in upstream source waters of the Pacific Ocean and the Bering Sea creates the conditions necessary to allow for the swift consumption of river nitrogen in the estuarine transition zone. This also suggests that North American rivers contribute to restore $\mathrm{N}^{*}$ toward its mean global value, even though the total transport of nitrogen by Arctic rivers currently remains small relative to the Bering Strait influx (Le Fouest et al., 2013). 


\section{Conclusions}

Our results provide new information and insights into the interplay of riverine and oceanic processes on a narrow interior Arctic shelf, and into the biogeochemical consequence of these processes at local and larger scales. The ratio of river discharge to shelf area is much higher for the narrow Mackenzie shelf than for the vast Siberian shelves, which should maximize the overall contribution of river nutrients to overall shelf productivity. Our estimates for 2009, a year of high discharge by the Mackenzie River, indicate that river nutrients had a small impact on primary production at the annual time scale and a moderate one during July and August. These impacts are limited partly because the narrow configuration of the shelf also magnifies the impact of upwelling at the shelf break. Although upwelling was weaker during our survey than at other times (e.g. Tremblay et al., 2011), it supported elevated primary production by providing nutrients to the lower euphotic zone where subsurface phytoplankton layers thrive (Martin et al., 2012; Carmack et al., 2004). Direct measurements of the uptake of different riverine DON and DOP sources were not performed in our study but indirect evidence suggests that their contribution to new production was minor during summer and that locally produced organic nutrients indirectly supported regenerated primary production which, based on DIN uptake measurements, represented a large portion of total primary production in the estuarine transition zone. The respective roles of benthic and pelagic processes on nutrient regeneration in this area remain to be assessed.

The regional impact of the Mackenzie River would be much different if (1) the waters supplied through the Bering Strait did not carry such a strong $\mathrm{P}^{*}$ anomaly, and (2) Pacificderived polar surface waters were not so strongly stratified in the interior. The first condition supplies a reservoir of excess $\mathrm{P}$ and the second one helps maintaining it by limiting the re-injection of mineralized nutrients with a higher $\mathrm{N}: \mathrm{P}$ into the euphotic zone. The same biogeochemical processes that lower the inflow of nitrate to the interior of the Arctic also create a setting in which labile $\mathrm{N}$ from North American Rivers can be readily used by coastal phytoplankton. Patterns of coastal nutrient use are presumably much different on Siberian shelves, where low nitrate : SRP river waters (e.g. 3.5 and 2.2 for the Yenisey and $\mathrm{Ob}$ rivers, respectively; Le Fouest et al., 2013) contribute to increase $\mathrm{P}^{*}$ since there is not enough inorganic $\mathrm{N}$ to support the consumption of excess marine P. Beyond its immediate impact on shelf productivity, the Mackenzie River helps to rectify the nitrogen deficit of waters exported into the western North Atlantic and to rise silicate levels in this outflow (Torres-Valdés et al., 2013). It follows that variability or change in the flow, nutrient load and nutrient stoichiometry of surface waters supplied to the Arctic Ocean by rivers and through the Bering Strait should impact marine productivity and biogeochemistry both locally and far downstream.

\section{The Supplement related to this article is available online at doi:10.5194/bg-11-4853-2014-supplement.}

Acknowledgements. This study was conducted as part of the MALINA Scientific Program funded by ANR (Agence Nationale de la Recherche), INSU-CNRS (Institut National des Sciences de l'Univers - Centre National de la Recherche Scientifique), CNES (Centre National d'Etudes Spatiales), ESA (European Space Agency) and the ArcticNet Canadian Network of Centres of Excellence. We thank all participants to the MALINA cruises for their help, especially K. Lévesque for the logistics and all of the CCGS Amundsen crew members. We also thank Robert Max Holmes, Lee Cooper and Richard McHorney (from the PARTNERS and Arctic-GRO projects) as well as Juanetta Sanderson and Robin Staples (Water Resources Division, Department of Indian Affairs and Northern Development) for their coordination and assistance in collecting water samples at Inuvik and Tsiigehtchic during spring and summer 2009. This study is a contribution to the scientific programs of Takuvik and Québec-Océan.

Edited by: E. Boss

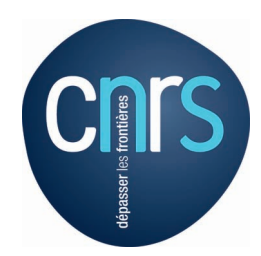

The publication of this article is financed by CNRS-INSU.

\section{References}

Aminot, A. and Kérouel, R.: Dosage automatique des nutriments dans les eaux marines: méthodes en flux continu, edited by: IFREMER, Méthodes d'analyse en milieu marin, 188 pp., 2007.

Benner, R.: Molecular indicators of the bioavailability of dissolved organic matter, in: Aquatic ecosystems: Interactivity of dissolved organic matter, edited by: Findlay, S. and Sinsabaugh, R., Elsevier, 121-137, 2003.

Bergeron, M. and Tremblay, J.-É.: Shifts in biological productivity inferred from nutrient drawdown in the southern Beaufort Sea (2003-2011) and northern Baffin Bay (19972011), Canadian Arctic, Geophys. Res. Lett., 41, 3979-3987, doi:10.1002/2014GL059649, 2014.

Blais, M., Tremblay, J.-É., Lovejoy, C., Jungblut, A. D., Gagnon, J., Martin, J., and Thaler, M.: Nitrogen fixation and identification of potential diazotrophs in the Canadian Arctic, Global Biogeochem. Cy., 26, GB3022, doi:10.1029/2011GB004096, 2012.

Bushaw-Newton, K. L. and Moran, M. A.: Photochemical formation of biologically available nitrogen from dissolved humic substances in coastal marine systems, Aquat. Microbial Ecol., 18, 285-292, doi:10.3354/ame018285, 1999.

Carmack, E. and MacDonald, R. W.: Oceanography of the Canadian Shelf of the Beaufort Sea: a setting for marine life, Arctic, 55, 29-45, 2002. 
Carmack, E. C., Macdonald, R. W., and Jasper, S.: Phytoplankton productivity on the Canadian Shelf of the Beaufort Sea, Mar. Ecol.-Prog. Ser., 277, 37-50, 2004.

Codispoti, L. A., Kelly, V., Thessen, A., Matrai, P., Suttles, S., Hill, V., Steele, M., and Light, B.: Synthesis of primary production in the Arctic Ocean: III. Nitrate and phosphate based estimates of net community production, Prog. Oceanogr., 110, 126-150, doi:10.1016/j.pocean.2012.11.006, 2013.

Deutsch, C. and Weber, T.: Nutrient Ratios as a Tracer and Driver of Ocean Biogeochemistry, in: Annual Review of Marine Science, Vol 4, edited by: Carlson, C. A., and Giovannoni, S. J., Annual Review of Marine Science, Annual Reviews, Palo Alto, 113-141, 2012.

Dugdale, R. C. and Goering, J. J.: Uptake of new and regenerated forms of nitrogen in primary productivity, Limnol. Oceanogr., 12, 196-206, 1967.

Emmerton, C. A., Lesack, L. F. W., and Vincent, W. F.: Nutrient and organic matter patterns across the Mackenzie River, estuary and shelf during the seasonal recession of sea-ice, J. Mar. Syst., 74, 741-755, 2008a.

Emmerton, C. A., Lesack, L. F. W., and Vincent, W. F.: Mackenzie River nutrient delivery to the Arctic Ocean and effects of the Mackenzie Delta during open water conditions, Global Biogeochem. Cy., 22, GB1024, doi:10.1029/2006GB002856, 2008 b.

Forest, A., Tremblay, J.-E., Gratton, Y., Martin, J., Gagnon, J., Darnis, G., Sampei, M., Fortier, L., Ardyna, M., Gosselin, M., Hattori, H., Nguyen, D., Maranger, R., Vaqué, D., Pedrós-Alió, C., Sallon, A., Michel, C., Kellogg, C., Deming, J., Shadwick, E., Thomas, H., Link, H., Archambault, P., and Piepenburg, D.: Biogenic carbon flows through the planktonic food web of the Amundsen Gulf (Arctic Ocean): A synthesis of field measurements and inverse modeling analyses, Progr. Oceanogr., 91, 410436, doi:10.1016/j.pocean.2011.05.002, 2011.

Geider, R. J. and La Roche, J.: Redfield revisited: variability of $\mathrm{C}: \mathrm{N}: \mathrm{P}$ in marine microalgae and its biochemical basis, Eur. J. Phycol., 37, 1-17, 2002.

Granger, J., Prokopenko, M. G., Sigman, D. M., Mordy, C. W., Morse, Z. M., Morales, L. V., Sambrotto, R. N., and Plessen, B.: Coupled nitrification-denitrification in sediment of the eastern Bering Sea shelf leads to N-15 enrichment of fixed N in shelf waters, J. Geophys. Res., 116, C11006, doi:10.1029/2010jc006751, 2011.

Gruber, N. and Sarmiento, J. L.: Global patterns of marine nitrogen fixation and denitrification, Global Biogeochem. Cy., 11, 235266, 1997.

Holmes, R. M., Aminot, A., Kérouel, R., Hooker, B. A., and Peterson, B. J.: A simple and precise method of measuring ammonium in marine and freshwater ecosytems, Can. J. Fish. Aquat. Sci., 56, 1801-1808, 1999.

Holmes, R. M., McClelland, J. W., Peterson, B. J., Shiklomanov, I. A., Shiklomanov, A. I., Zhulidov, A. V., Gordeev, V. V., and Bobrovitskaya, N. N.: A circumpolar perspective on fluvial sediment flux to the Arctic Ocean, Global Biogeochemical Cy., 16, 1098, doi:10.1029/2001GB001849, 2002.

Holmes, R. M., McClelland, J. W., Peterson, B. J., Tank, S. E., Bulygina, E., Eglinton, T. I., Gordeev, V. V., Gurtovaya, T. Y., Raymond, P. A., Repeta, D. J., Staples, R., Striegl, R. G., Zhulidov, A. V., and Zimov, S. A.: Seasonal and Annual Fluxes of Nutrients and Organic Matter from Large Rivers to the Arc- tic Ocean and Surrounding Seas, Estuar. Coasts, 35, 369-382, doi:10.1007/s12237-011-9386-6, 2012.

Kalvelage, T., Jensen, M. M., Contreras, S., Revsbech, N. P., Lam, P., Gunter, M., LaRoche, J., Lavik, G., and Kuypers, M. M. M.: Oxygen Sensitivity of Anammox and Coupled N-Cycle Processes in Oxygen Minimum Zones, PLoS One, 6, e29299, doi:10.1371/journal.pone.0029299, 2011.

Kirkwood, D. S.: Stability of solutions of nutrients salts during storage, Mar. Chem., 38, 151-164, 1992.

Lansard, B., Mucci, A., Miller, L. A., Macdonald, R. W., and Gratton, Y.: Seasonal variability of water mass distribution in the southeastern Beaufort Sea determined by total alkalinity and delta O-18, J. Geophys. Res., 117, C03003, doi:10.1029/2011jc007299, 2012.

Le Fouest, V., Babin, M., and Tremblay, J.-É.: Fate of riverine nutrients in Arctic Ocean shelf waters, Biogeosciences, 10, 36613677, doi:10.5194/bg-10-3661-2013, 2013.

Li, W. K. W., McLaughlin, F. A., Lovejoy, C., and Carmack, E. C.: Smallest algae thrive as the Arctic Ocean freshens, Science, 326, 5952, doi:10.1126/science.1179798, 2009.

Link, H., Chaillou, G., Forest, A., Piepenburg, D., and Archambault, P.: Multivariate benthic ecosystem functioning in the Arctic - benthic fluxes explained by environmental parameters in the southeastern Beaufort Sea, Biogeosci., 10, 5911-5929, doi:10.5194/bg-10-5911-2013, 2013.

Lovejoy, C., Vincent, W. F., Bonilla, S., Roy, S., Martineau, M. J., Terrado, R., Potvin, M., Massana, R., and Pedros-Alio, C.: Distribution, phylogeny, and growth of cold-adapted picoprasinophytes in arctic seas, J. Phycol., 43, 78-89, 2007.

Martin, J., Tremblay, J. É., and Price, N. M.: Nutritive and photosynthetic ecology of subsurface chlorophyll maxima in Canadian Arctic waters, Biogeosciences, 9, 5353-5371, doi:10.5194/bg-95353-2012, 2012.

McClelland, J. W., Holmes, R. M., Dunton, K. H., and Macdonald, R. W.: The Arctic Ocean Estuary, Estuar. Coasts, 35, 353-368, doi:10.1007/s12237-010-9357-3, 2012.

Michel, C., Ingram, G., and Harris, L. R.: Variability in oceanographic and ecological processes in the Canadian Arctic Archipelago, Prog. Oceanogr., 71, 379-401, 2006.

Mills, M. M. and Arrigo, K. R.: Magnitude of oceanic nitrogen fixation influenced by the nutrient uptake ratio of phytoplankton, Nat. Geosci., 3, 412-416, doi:10.1038/ngeo856, 2010.

Moritz, R. E., Bitz, C. M., and Steig, E. J.: Dynamics of recent climate change in the Arctic, Science, 297, 1497-1502, doi:10.1126/science.1076522, 2002.

Ortega-Retuerta, E., Jeffrey, W. H., Babin, M., Bélanger, S., Benner, R., Marie, D., Matsuoka, A., Raimbault, P., and Joux, F.: Carbon fluxes in the Canadian Arctic: patterns and drivers of bacterial abundance, production and respiration on the Beaufort Sea margin, Biogeosciences, 9, 3679-3692, doi:10.5194/bg-9-36792012, 2012.

Raimbault, P., Slawyk, G., Coste, B., and Fry, J.: Feasibility of using an automated colorimetric procedure for the determination of seawater nitrate in the 0 to $100 \mathrm{nM}$ range: Examples from field and culture, Mar. Biol., 104, 347-351, 1990.

Raimbault, P., Diaz, F., Pouvesle, W., and Boudjellal, B.: Simultaneous determination of particulate organic carbon, nitrogen and phosphorus collected on filters, using a semi-automatic wetoxidation method, Mar. Ecol.-Prog. Ser., 180, 289-295, 1999a. 
Raimbault, P., Pouvesle, W., Diaz, F., Garcia, N., and Sempere, R.: Wet-oxidation and automated colorimetry for simultaneous determination of organic carbon, nitrogen and phosphorus dissolved in seawater, Mar. Chem., 66, 161-169, doi:10.1016/s0304-4203(99)00038-9, 1999b.

Raimbault, P., Slawyk, G., Boudjellal, B., Coatanoan, C., Conan, P., Coste, B., Garcia, N., Moutin, T., and Pujo-Pay, M.: Carbon and nitrogen uptake and export in the equatorial Pacific at 150 degrees W: Evidence of an efficient regenerated production cycle, J. Geophys. Res., 104, 3341-3356, doi:10.1029/1998jc900004, 1999c.

Retamal, L., Bonilla, S., and Vincent, W. F.: Optical gradients and phytoplankton production in the Mackenzie River and the coastal Beaufort Sea, Polar Biol., 31, 363-379, doi:10.1007/s00300007-0365-0, 2008.

Shen, Y., Fichot, C. G., and Benner, R.: Dissolved organic matter composition and bioavailability reflect ecosystem productivity in the Western Arctic Ocean, Biogeosciences, 9, 4993-5005, doi:10.5194/bg-9-4993-2012, 2012.

Simpson, K. G., Tremblay, J. E., Gratton, Y., and Price, N. M.: An annual study of inorganic and organic nitrogen and phosphorus and silicic acid in the southeastern Beaufort Sea, J. Geophys. Res., 113, C07016, doi:10.1029/2007JC004462, 2008.

Spears, B. M. and Lesack, L. F. W.: Bacterioplankton production, abundance, and nutrient limitation among lakes of the Mackenzie Delta (western Canadian arctic), Can. J. Fish. Aquat. Sci., 63, 845-857, doi:10.1139/f05-264, 2006.

Squires, M. M. and Lesack, L. F. W.: The relation between sediment nutrient content and macrophyte biomass and community structure along a water transparency gradient among lakes of the Mackenzie Delta, Can. J. Fish. Aquat. Sci., 60, 333-343, doi:10.1139/f03-027, 2003.

Tank, S. E., Manizza, M., Holmes, R. M., McClelland, J. W., and Peterson, B. J.: The Processing and Impact of Dissolved Riverine Nitrogen in the Arctic Ocean, Estuar. Coasts, 35, 401-415, doi:10.1007/s12237-011-9417-3, 2012.
Tarr, M. A., Wang, W. W., Bianchi, T. S., and Engelhaupt, E.: Mechanisms of ammonia and amino acid photoproduction from aquatic humic and colloidal matter, Water Res., 35, 3688-3696, doi:10.1016/s0043-1354(01)00101-4, 2001.

Torres-Valdés, S., Tsubouchi, T., Bacon, S., Naveira-Garabato, A. C., Sanders, R., McLaughlin, F. A., Petrie, B., Kattner, G., Azetsu-Scott, K., and Whitledge, T. E.: Export of nutrients from the Arctic Ocean, J. Geophys. Res.-Oceans, 118, 1625-1644, doi:10.1002/jgrc.20063, 2013.

Tremblay, J. E. and Gagnon, J.: The effects of irradiance and nutrient supply on the productivity of Arctic waters: a perspective on climate change, in: Influence of Climate Change on the Changing Arctic and Sub-Arctic Conditions, edited by: Nihoul, J. C. J. and Kostianoy, A. G., Nato Science for Peace and Security Series C - Environmental Security, Elsevier, 73-93, 2009.

Tremblay, J. E., Gratton, Y., Carmack, E. C., Payne, C. D., and Price, N. M.: Impact of the large-scale Arctic circulation and the North Water Polynya on nutrient inventories in Baffin Bay, J. Geophys. Res., 107, C83112, doi:10.1029/2000JC000595, 2002.

Tremblay, J.-E., Simpson, K., Martin, J., Miller, L., Gratton, Y., Barber, D., and Price, N. M.: Vertical stability and the annual dynamics of nutrients and chlorophyll fluorescence in the coastal, southeast Beaufort Sea, J. Geophys. Res., 113, C07S90, doi:10.1029/2007JC004547, 2008.

Tremblay, J.-É., Bélanger, S., Barber, D. G., Asplin, M., Martin, J., Gagnon, J., Fortier, L., Darnis, G., Gratton, Y., Williams, W. J., Link, H., Archambault, P., Philippe, B., and Gosselin, M.: Climate forcing multiplies biological productivity in the coastal Arctic Ocean, Geophys. Res. Lett., 38, L18604, doi:10.1029/2011GL048825, 2011.

Xie, H., Bélanger, S., Song, G., Benner, R., Taalba, A., Blais, M., Tremblay, J.-É., and Babin, M.: Photoproduction of ammonium in the southeastern Beaufort Sea and its biogeochemical implications, Biogeosciences, 9, 3047-3061, doi:10.5194/bg-9-30472012, 2012.

Yamamoto-Kawai, M., Carmack, E., and McLaughlin, F.: Nitrogen balance and Arctic throughflow, Nature, 443, 7107, doi:10.1038/443043a, 2006. 